\title{
ARBOREOUS SPECIES POPULATION IN A TOPOGRAPHIC GRADIENT OF MIXED OMBROPHILOUS FOREST IN RIO GRANDE DO SUL
}

\author{
Igor da Silva Narvaes ${ }^{1}$; Solon Jonas Longhi ${ }^{2}$, Ricardo Vargas Kilca ${ }^{3}$; Tales Eduardo Sangoi Rodrigues ${ }^{4}$ \\ ${ }^{1}$ Forest Engineer, Dr., INPE/CRA, Belém, PA, Brazil - igor.narvaes@inpe.br \\ ${ }^{2}$ Forest Engineer, Dr., UFSM, Santa Maria, RS, Brazil - longhi.solon@gmail.com \\ 3Biologist, M.Sc., PPG-Eng. Forestry, UFSM, Santa Maria, RS, Brazil - rvkilka@gmail.com \\ ${ }^{4}$ Forest Engineer, Environmental Consultant, Porto Alegre, RS, Brazil - talesmegaforest@ yahoo.com.br
}

Received for publication: 16/08/2013 - Accepted for publication: 24/04/2014

\begin{abstract}
This study was part of the Long Term Ecological Project (PELD) conducted in the São Francisco de Paula National Forest, RS where Mixed Ombrophilous Forest is predominant. The aim was to identify distribution of arboreous species depending on different soil conditions occurring in the low, medium and upper slopes of the studied area. 180 sample units of $100 \mathrm{~m}^{2}$ distributed along the topographical gradient were installed, with identification of the totality of arboreous species with $3 \mathrm{~cm} \leq \mathrm{CBH}<30$ $\mathrm{cm}$ and height exceeding 1.30 meters. In addition, thirteen environmental variables were collected in each sub-unit. The Canonical Correspondence Analysis model (CCA) indicated that only the slope, the topographic position, the stoniness and the soil color (up to $50 \mathrm{~cm}$ in depth) were the variables that best distinguished the sample groups of the slope environments. Out of the 53 species included in the model, ten species showed best correlations with the typical environments of upper slopes and 12 species were most characteristics of the lower positions, while the remaining resulted well adapted to different hillside topographic conditions. Environmental preferences of the species could be considered in silvicultural and recuperation programs applied to hillside environments of the region.

Keywords: Araucarian Forest; species distribution pattern, edaphic characteristics; canonical correspondence analysis.
\end{abstract}

\section{Resumo}

Ocupação de espécies arbóreas em um gradiente topográfico na Floresta Ombrófila Mista no Rio Grande do Sul. O presente estudo foi parte do Projeto Ecológico de Longa Duração (PELD), realizado na Floresta Nacional de São Francisco de Paula, RS, onde predomina a Floresta Ombrófila Mista. O objetivo foi identificar relações de distribuição das espécies arbóreas em diferentes condições edáficas que ocorrem em posições inferiores, médias e superiores em encostas na área de estudo. Foram instaladas 180 subunidades amostrais de $100 \mathrm{~m}^{2}$ distribuídas ao longo dessas encostas, identificados todos os indivíduos arbóreos com $3 \mathrm{~cm} \leq \mathrm{CAP}<30 \mathrm{~cm}$ e altura superior a 1,30 metros, além de13 variáveis ambientais inventariadas em cada subunidade. O modelo de Análise de Correspondência Canônica (ACC) indicou que a variação na declividade, na posição topográfica, na pedregosidade e na cor dos solos (na profundidade de até $50 \mathrm{~cm}$ ) foram as variáveis que melhor distinguiram os grupos de parcelas que caracterizaram os ambientes das encostas. Das 53 espécies inseridas no modelo, dez espécies demonstraram maiores correlações com os ambientes típicos das encostas superiores e 12 espécies foram mais características das posições inferiores, enquanto que as demais apresentaram ampla adaptação às diferentes posições das encostas. As preferências ambientais das espécies poderiam ser consideradas em programas silviculturais e de recuperação nos ambientes de encostas na região.

Palavras-chave: Floresta com Araucária; padrão de distribuição de espécies; características edáficas; análise de correspondência canônica.

\section{INTRODUCTION}

In Rio Grande do Sul, Mixed Ombrophilous Forest is characterized by tropical (Afro-Brazilian) and temperate (Austral-Antarctica and Andean) flora, with great physiognomic relevance of Coniferaceae 
and Lauraceae elements (MARCHIORI, 2002). This forest structure suffered great environmental degradation and reduction of its original area of distribution mainly due to forest resources extraction, in particular for the species Araucaria angustifolia (Bertol.) Kuntze, whose timber has great commercial value (LADEIRA, 2002). Thus, development of scientific researches in the area of ecology and silviculture is necessary to subside sustainable forest management programs and conservation of biodiversity in this type of forest.

The way a forest regenerates depends on mechanisms helping seed germination to establish new individuals and species (ÁVILA et al., 2011), like seed rain, soil seed bank and the seedlings bank. These mechanisms may be influenced by different types of microclimates within the forest, name "microsites", which act directly on the forest regeneration process.

Therefore, in the analysis of forest inventories, the application of multivariate techniques is very important, to demonstrate the relationship between sampled species and common microsites of the studied community, thus providing information about autoecology of forest species and so great technical bases to the development of a sustainable forest management (BARIK et al, 1996). The Canonical Correspondence Analysis (CCA) have been a frequently used multivariate technique in Brazilian forest studies, to describe relationships between plant species and various environmental variables (OLIVEIRAFILHO et al., 1998; PINDER; ROSSO, 1998; BLANC et al., 2000; SCIPIONI et al., 2010; GRAF NETO, 2011).

In this way, Narvaes et al. (2008) analyzed the floristic composition of natural regeneration in the Mixed Ombrophilous Forest of the National Forest (FLONA) in São Francisco de Paula, RS and demonstrated, through grouping analysis, the presence of three floristic groups which could be related to the different environments encountered along a topographic gradient: lower, medium and higher hillsides.

Considering diversity and complexity of the microhabitats studied in this analysis, this study is based on the hypothesis that naturally regenerating species behave according to a preferential colonization/distribution standard, following the microsites conditions which depend on the topographic gradient variation.

In this context, this study aimed to identify the relationship between the analyzed sub-unities and sampled species, depending on the environmental factors encountered in the lower, medium and higher portions of a hillside, physically defined as permanent stands in the FLONA of São Francisco de Paula, RS.

\section{MATERIAL AND METHODS}

\section{Studied area}

This study was conducted in the FLONA of São Francisco de Paula, RS, located between coordinates $29^{\circ} 23^{\prime}$ and $29^{\circ} 27^{\prime} \mathrm{S}, 50^{\circ} 23^{\prime}$ and $50^{\circ} 25^{\prime} \mathrm{W}$, with a total area of $1.606,69$ hectares, being 901,9 ha of native forests (56.1\%). Climate is "Cfb" type, oceanic climate (Köppen classification), with average temperature of the hottest month (January) around $20{ }^{\circ} \mathrm{C}$; during winter the average of daily minimum temperatures is below $6{ }^{\circ} \mathrm{C}$, with thermic average lower than $10^{\circ} \mathrm{C}$, at least in July (MORENO, 1961). Rainfall is well distributed along the year, with a yearly average of 2,252 mm (NIMER, 1990). Predominant soil is Cha 1, typical Alumic Humic Cambisol (SANTOS et al., 2013; STRECK et al., 2008).

Terrain relief is undulating in the north side with $930 \mathrm{~m}$ height, and in the south side is hilly and forms more than $100 \mathrm{~m}$ deep Canyons, characteristic of the area where the study was conducted (SANTOS et al., 2013). However, analyzing the location of the permanent stands, their height and corresponding mean declivity, variation was from 844 to 911 meters and from 4.7 to $40.3 \%$ respectively, demonstrating great relief variation in the studied area. Height and declivity values were extracted using a digital topographic model, originated by refinement by kriging of SRTM - Shuttle Radar Topography Mission data, called TOPODATA, with a spatial resolution of $30 \mathrm{~m}$ (VALERIANO; ROSSETI, 2012). Furthermore, according to the classification by Santos et al. (2013), crossing the location of permanent stands with declivity classes proposed, using derivation generated from TOPODATA, it was highlighted that permanent stand 1 is located in a relief with 3-8\% declivity (gentle slope-undulating); stand 2 in a relief with 20-45\% declivity (steep-undulating); stands 3 and 4 in a relief with $8-20 \%$ declivity (undulating); while stands 5 and 6 in a relief with $20-45 \%$ declivity (steep-undulating).

More specifically, when micro reliefs within each stand are analyzed, sub-unities of the lower 
hillside have gentle declivity, while in the middle hillside the wide majority of stands vary between medium and steep declivity, although many gentle declivities were observed in the analyzed sub-unities $(10 \times 10 \mathrm{~m})$. In the upper hillside almost all sub-unities presented steep declivity.

Vegetation is constituted by a mosaic of species, with predominance of Araucaria angustifolia Bertol O. Kuntze, associated to species like Casearia decandra Jacq., Stillingia oppositifolia Baill. ex Müll.Arg., Sebastiania brasiliensis Spreng., Rudgea parquioides (Cham.) Müll.Arg, Matayba elaeagnoides Radlk., Myrsine umbellata Mart., Myrceugenia cucullata D. Legrand., Calyptranthes concinna DC., Campomanesia rhombea O. Berg. and Blepharocalyx salicifolius (Kunth) O. Berg (NARVAES et al., 2005)

\section{Collection and analysis of data}

Inside the studied area, 6 permanent stands were previously chosen, with average linear distance of 1.200 meters each other, in a way that they initially include a wide variation of sites, characterizing lower, middle and upper positions of the analyzed hillsides. Those permanent stands $(100 \mathrm{x} 100 \mathrm{~m}$ unities) belong to the Long Term Ecological Project (PELD).

In 2002 , thirty sub-unities $10 \times 10 \mathrm{~m}\left(100 \mathrm{~m}^{2}\right)$ were drawn in each stand (total 1.8 ha), distributed in 90 sub-unities in the lower position of the hillside, 60 sub-unities in the middle hillside and 30 subunities in the higher hillside. In each sub-unity, all arboreal individuals taller than $1.30 \mathrm{~m}$ and with circumference at breast height between $3 \mathrm{~cm} \leq \mathrm{CBH}<30 \mathrm{~cm}$ were sampled. In this way, the evaluated arboreal component included young individuals (in regeneration) and adult specimens (established) of the community. Species with supporting and climbing habit were grouped as lianas. Those individuals were numbered and, when not identified in field, botanic material was collected to be compared to dried samples in the Herbarium of Forest Sciences Department (HDCF) of the Universidade Federal de Santa Maria. Taxonomic classification of species followed the Classification System of Angiosperm Phylogeny Group III (APG III, 2009).

To analyze correlations between environmental and vegetational gradients, the Canonic Correspondence Analysis (CCA) (TER BRAAK, 1987) was applied, using PC-ORD software version 3.17 for Windows (MCCUNE; MEFFORD, 1997). CCA is based on value of chi-squared distance, such that samples are weighted according to their totals, which provides heavy weights for species whose total density in data matrix is low, this way exaggerating distinction of samples containing various rare species (MC CUNE; MEFFORD, 1995; 1997). Thus, the matrix of density of the species was formed by the number of individuals per stand of species with ten or more individuals detected. Following recommendations of Ter Braak (1995), density values (x) were transformed by the expression $\ln (\mathrm{x}+1)$ to compensate deviations caused by some high values. Dead individuals, unidentified (three species) and low density individuals ( $<10$ ind.) and with similar densities in the three hillside positions (eight individuals), were discarded since they did not contribute to CCA calculations. A total of 57 species contributed to establish correlations with the environmental variables (Table 1).

Categories of the listed environmental variables (second matrix) were obtained inside each sampling sub-unit $\left(100 \mathrm{~m}^{2}\right)$, according to the methodology established by Narvaes (2004): a) exposition: 1 . North, 2. South, 3. East, 4. West, 5. Northeast, 6. Southeast, 7. Northeast, 8. Southwest; b) declivity: 1. Smooth $\left(0^{\circ}\right.$ to $\left.10^{\circ}\right), 2$. Medium $\left(10^{\circ}\right.$ to $\left.20^{\circ}\right)$ and, 3. Steep $\left(>20^{\circ}\right)$; topographic position: 1 . Lower hillside, 2 . Middle hillside and, 3. Upper hillside; d) canopy closure: 1. Very closed (relative luminous incidence between $0-0.99 \%$ ), 2. Closed (relative luminous incidence between 1-2.99\%), 3. Slightly open (relative luminous incidence between 3-5.99\%), 4. Open (relative luminous incidence of 6\% or more); e) soil depth: 1. Very shallow (from 0 to $50 \mathrm{~cm}$ depth), 2. Shallow (from 50 to $75 \mathrm{~cm}$ depth) and, 3. Moderately deep (more than $75 \mathrm{~cm}$ deep); soil color: 1. 5YR hue (value between 2.5 and 5, chroma between 1 and 6 ) - redyellow hue, 2. 7.5YR hue (value between 4 and 6, chroma between 2 and 4 ) - red-yellow hue, 3. 10R hue (value between 2.5 and 4, chroma between 2 and 6) - red hue, 4. 10YR hue (value between 2.5 and 5, chroma between 1 and 6) - yellow hue, analyzed in the different studied depths, from the mean coloration observed spading five points (corners and center of each sub-unity), using the Munsell chart (Munsell Color Company, 1971); g) stoniness: 1 . Low (less than 33\% of surfacing rocks), 2. Medium (quantity of rocks between 33 and 66\%) and, 3. High (quantity of rocks above 66\%), determined for the total analyzed surface; and h) humidity: 1. Low humidity (well-drained soil), 2. Medium humidity (presence of small flooded areas), 3. High humidity (soaked soil and/or with presence of flooded areas). 
Humidity was introduced in the environmental variables as a form to assess the hypothesis that water and dissolved mineral nutrients could be determining the distribution of forest species (BOTREL et al., 2002). Also variables as basal area and frequency distribution of growing stock were assessed. Original from the PELD project, these two variables could present direct influence on composition and distribution of the natural regeneration, through seed rain, directly responsible for the appearance of seedlings in the remaining natural forest (CHAMI et al., 2011).

Following the statistical procedure established by Botrel et al. (2002), a preliminary CCA was applied, discarding eight environmental variables strongly correlated or highly redundant with other variables. Of all the sampled species, the ones which presented similar density values in two or more topographic positions were discarded from the analysis, since they could cause the increase of residual variance that is not explained in the final model (TER BRAAK, 1995; MC CUNNE; MEFFORD, 1997).

Final CCA was processed with the five most representative variables, more strongly correlated with the ordination axes, in decreasing order of importance: topographic position, soil color up to $50 \mathrm{~cm}$ depth, humidity, declivity, stoniness and soil depth. Significance between matrixes was verified by the Monte Carlo permutation method, using 1,000 permutations, aiming to increase precision in calculation of probability.

\section{RESULTS AND DISCUSSION}

\section{Floristic composition}

Database of species considered in the CCA included 53 arboreous species belonging to 22 botanic families. The species Senegalia bonariensis (Gillies ex Hook. \& Arn.) Seigler \& Ebinger, Dalbergia frutescens (Vell.) Britton., Strychnos brasiliensis (Spreng.) Mart., Seguieria aculeata Jacq. and Solanum sanctaecatharinae Dunal were grouped into a class named lianas. Individual densities of species in different hillside positions can be observed in table 1.

Table 1. Arboreous and shrub species density in the different positions of the hillsides in São Francisco de Paula National Forest, Rio Grande do Sul State.

Tabela 1. Densidade das espécies arbóreas e arbustivas nas diferentes posições de encostas na FLONA de São Francisco de Paula, RS.

\begin{tabular}{|c|c|c|c|c|}
\hline Family/species & Cod. & Low. & Mid. & Upp. \\
\hline \multicolumn{5}{|l|}{ ANNONACEAE } \\
\hline Annona rugulosa (Schltdl.) H.Rainer & Anno rug & 40 & 27 & 9 \\
\hline \multicolumn{5}{|l|}{ AQUIFOLIACEAE } \\
\hline Ilex dumosa Reissek & Ilex dum & 1 & 5 & 16 \\
\hline Ilex microdonta Reissek & Ilex micr & 0 & 0 & 12 \\
\hline $\begin{array}{l}\text { Ilex paraguariensis A. St.-Hil. } \\
\text { ARAUCARIACEAE }\end{array}$ & Ilex parag & 80 & 107 & 19 \\
\hline $\begin{array}{l}\text { Araucaria angustifolia (Bertol.) Kuntze } \\
\text { CELASTRACEAE }\end{array}$ & Arauc ang & 24 & 3 & 14 \\
\hline $\begin{array}{l}\text { Maytenus evonymoides Reissek } \\
\text { CIPÓS }\end{array}$ & Mayt evon & 36 & 45 & 2 \\
\hline $\begin{array}{l}\text { Cipós } \\
\text { CUNONIACEAE }\end{array}$ & Cipos & 168 & 68 & 54 \\
\hline $\begin{array}{l}\text { Lamanonia ternata Vell. } \\
\text { EUPHORBIACEAE }\end{array}$ & Lama tern & 82 & 11 & 59 \\
\hline Sebastiania brasiliensis Spreng. & Sebst bras & 968 & 537 & 29 \\
\hline Sebastiania commersoniana (Baill.) L.B. Sm. \& Downs. & Sebst com & 64 & 8 & 5 \\
\hline Stillingia oppositifolia Baill. ex Müll.Arg. & Still oppo & 2166 & 327 & 127 \\
\hline $\begin{array}{l}\text { Lonchocarpus nitidus (Vogel) Benth } \\
\text { LAURACEAE }\end{array}$ & Lonch niti & 12 & 29 & 0 \\
\hline Cinnamoтиm glaziovii (Mez) Kosterm. & Cin glaz & 87 & 30 & 1 \\
\hline Cryptocarya aschersoniana Mez. & Crypt asc & 130 & 17 & 22 \\
\hline Nectandra megapotamica (Spreng.) Mez. & Nect meg & 12 & 23 & 12 \\
\hline
\end{tabular}




\begin{tabular}{|c|c|c|c|c|}
\hline Ocotea diospyrifolia (Meisn.) Mez & Ocot dios & 0 & 3 & 26 \\
\hline Ocotea indecora (Shott) Mez & Ocot inde & 133 & 0 & 52 \\
\hline Ocotea pulchella (Nees) Mez & Oct pulc & 19 & 29 & 70 \\
\hline \multicolumn{5}{|l|}{ MALVACEAE } \\
\hline Luehea divaricata Mart. & Lueh divar & 6 & 22 & 0 \\
\hline Mollinedia elegans Tul. & Molli eleg & 39 & 49 & 108 \\
\hline \multicolumn{5}{|l|}{ MYRTACEAE } \\
\hline Blepharocalyx salicifolius (Kunth) O.Berg & Blef salic & 107 & 55 & 9 \\
\hline Calyptranthes concinna DC. & Calip conc & 176 & 114 & 37 \\
\hline Campomanesia rhombea $\mathrm{O}$. Berg. & Camp rom & 158 & 43 & 16 \\
\hline Eugenia involucrata DC. & Eug invol & 23 & 19 & 9 \\
\hline Eugenia subterminalis DC. & Eug subt & 30 & 20 & 0 \\
\hline Eugenia uruguayensis Cambess. & Eug urug & 30 & 15 & 9 \\
\hline Myrceugenia cucullata D. Legrand. & Myrc cuc & 180 & 164 & 29 \\
\hline Myrceugenia foveolata (O.Berg) Sobral & Myrc fove & 0 & 11 & 0 \\
\hline Myrceugenia miersiana (Gardner) D. & Myrc mier & 80 & 22 & 13 \\
\hline Myrceugenia myrcioides (Cambess.) O. Berg & Myrc myrc & 198 & 35 & 6 \\
\hline Myrceugenia oxysepala (Burret) D.Legrand \& Kausel & Myrc oxys & 238 & 188 & 14 \\
\hline Myrcia oligantha $\mathrm{O}$. Berg & Myrc oli & 124 & 53 & 66 \\
\hline Myrciaria delicatula (DC.) O. Berg & Myrc deli & 1 & 3 & 15 \\
\hline Myrciaria floribunda (West ex Willd.) O. Berg & Myrc flo & 38 & 6 & 14 \\
\hline Myrrhinium atropurpureum Schott & Myrr atrop & 28 & 9 & 11 \\
\hline \multirow{2}{*}{\multicolumn{5}{|c|}{ PICRAMNIACEAE }} \\
\hline & & & & \\
\hline Picramnia parvifolia Engl. & Picr parv & 18 & 7 & 3 \\
\hline \multicolumn{5}{|l|}{ PODOCARPACEAE } \\
\hline Podocarpus lambertii Klotzsch ex Endl. & Podoc lam & 7 & 2 & 23 \\
\hline \multicolumn{5}{|l|}{ PROTEACEAE } \\
\hline Roupala brasiliensis Klotzsch. & Roup bras & 38 & 12 & 13 \\
\hline \multicolumn{5}{|l|}{ RHAMNACEAE } \\
\hline Scutia buxifolia Reissek. & Scut buxi & 0 & 16 & 2 \\
\hline \multicolumn{5}{|l|}{ ROSACEAE } \\
\hline Prunus myrtifolia (L.) Urb. & Prun myrt & 57 & 9 & 19 \\
\hline \multicolumn{5}{|l|}{ RUBIACEAE } \\
\hline Rudgea parquioides (Cham.) Müll.Arg & Rudg parq & 325 & 28 & 527 \\
\hline \multicolumn{5}{|l|}{ RUTACEAE } \\
\hline Zanthoxylum petiolare A. St.-Hil. \& Tul. & Zant peti & 0 & 5 & 64 \\
\hline \multicolumn{5}{|l|}{ SALICACEAE } \\
\hline Casearia decandra Jacq. & Case dec & 1116 & 389 & 463 \\
\hline Xylosma pseudosalzmanii Sleumer & Xylos pse & 26 & 43 & 5 \\
\hline \multicolumn{5}{|l|}{ SAPINDACEAE } \\
\hline Allophylus edulis (A. St.-Hil.) Radlk. & All edu & 14 & 57 & 3 \\
\hline Allophylus guaraniticus (A. St.-Hil.) Radlk. & All guar & 19 & 189 & 0 \\
\hline Cupania vernalis Cambess. & Cupan ver & 79 & 40 & 14 \\
\hline Matayba elaeagnoides Radlk. & Matay ela & 404 & 61 & 23 \\
\hline \multicolumn{5}{|l|}{ SOLANACEAE } \\
\hline Brunfelsia cuneifolia J.A.Schmidt & Brun cun & 26 & 7 & 19 \\
\hline \multicolumn{5}{|l|}{ THEACEAE } \\
\hline Laplacea fruticosa (Schrad.) Kobuski & Lapla frut & 1 & 0 & 60 \\
\hline \multicolumn{5}{|l|}{ VERBENACEAE } \\
\hline Duranta vestita Cham. & Duran vest & 1 & 5 & 14 \\
\hline Lippia ramboi Moldenke & Lippia ram & 35 & 20 & 5 \\
\hline
\end{tabular}

Cod : code of the species in the CCA ordination axis. Low.: lower hillside, Mid: middle hillside and Upp.: upper hillside. 


\section{Ordination of environmental variables and species.}

CCA eigenvalues for the three ordination axes were 0.233 (axis 1), 0.159 (axis 2) and 0.086 (axis 3 ), representing respectively $6.6 \%$ (axis 1 ), $4.7 \%$ (axis 2) and $2.5 \%$ (axis 3 ) of their variability. On the whole, the three axes explained $14 \%$ of the global data variance, indicating high "noise" or unexplained residual variance. Nevertheless, significance of relationships species-environment was not impaired, since CCA produced considerable correlations in the three axes: 0.786 (axis 1), 0.706 (axis 2) and 0.699 (axis 3), highlighting balanced contribution of the three ordination axes. Those values of the coefficient of the generated model can be considered similar to the study of Botrel et al., (2002), for ten chemical and textural soil variables and two topographic variables, and inferior to another study conducted by Martins et al., (2003), for eleven chemical and textural variables, where texture classes were assessed depending on different contents of coarse sand, thin sand, silt and clay (SANTOS et al., 2013). Both studies had the objective to ultimately assess the effects of topographic variations on the floristic composition of semievergreen seasonal forest environments, in different regions.

Monte Carlo permutation test, for the three ordination axes, demonstrated that correlations between density of species in the sampling sub-units and environmental variables were significant at 5\% level of probability. These results indicate the existence of an environmental gradient, with some species confined to specific sampling sub-units along this gradient.

The more strongly correlated environmental variables, that is to say the ones with greater adjusted correlation values (TER BRAAK, 1987) with the first axis were, in decreasing order, topographic position and declivity, while soil color $(\leq 50 \mathrm{~cm})$ and stoniness emerged with the second axis. The third ordination axis had soil humidity and soil color as the environmental variables with the best correlation.

Fávero et al. (2009); Gotelli and Ellison (2011) explain that these weighted correlations are obtained through a linear relationship, elaborated by correlation or variance/covariance matrixes, which reflect and maximize only linear relationships between two groups of variables, both metric and not metric.

Table 2. Canonical correspondence analysis (CCA) with canonical coefficients and internal correlations ('intraset') in the two first ordination axis and weighted correlation matrix for the environmental variables used in the analysis.

Tabela 2. Análise de correspondência canônica (ACC) com os coeficientes canônicos e as correlações internas ('intraset') nos dois primeiros eixos de ordenação e a matriz de correlações ponderadas para as variáveis ambientais utilizadas na análise.

\begin{tabular}{|c|c|c|c|c|c|c|c|c|}
\hline \multirow{2}{*}{$\begin{array}{l}\text { Environmental } \\
\text { variables* }\end{array}$} & \multicolumn{3}{|c|}{ Weighted correlation } & \multirow{2}{*}{$\mathbf{U}$} & \multirow{2}{*}{ CS } & \multirow[b]{2}{*}{$\mathbf{P}$} & \multirow{2}{*}{ D } & \multirow{2}{*}{ PT } \\
\hline & Axis1 & Axis 2 & Axis 3 & & & & & \\
\hline $\mathrm{U}$ & $-0,136$ & $-0,376$ & $-0,915$ & 1,000 & $-0,247$ & 0,014 & $-0,208$ & $-0,050$ \\
\hline CS & $-0,031$ & $-0,771$ & 0,597 & - & 1,000 & 0,367 & $-0,200$ & $-0,565$ \\
\hline$P$ & 0,048 & $-0,552$ & 0,165 & - & - & 1,000 & 0,073 & $-0,222$ \\
\hline D & 0,715 & 0,158 & 0,065 & - & - & - & 1,000 & 0,662 \\
\hline PT & 0,835 & 0,478 & $-0,269$ & - & - & - & - & 1,000 \\
\hline
\end{tabular}

*U: Soil humidity, CS: Soil color $(\leq 50 \mathrm{~cm})$, P: Stoniness, D: Declivity, PT: Topographic position. Numbers in bold show the greatest correlations $(>0.5 \%)$ of variables with the ordination axes.

Weighted correlations showed strong interrelations between some variables, particularly between topographic position and declivity, and between topographic position and soil color $(<50 \mathrm{~cm})$. This confirms the proposition verified by Cattanio et al., (2002), that physical and chemical properties of soil are in relationship with the variation of water content.

Ordination of sampling sub-units in the two main axes of the model demonstrated the existence of sub-unities groups which represented very well the variability of the three hillside environments (topographic position) and of declivity, and the consequent edaphic variation between the stands, mainly in terms of soil color and stoniness (Figure 1).

Considering the environmental characteristics, the darker soil tones observed in sub-unities of the lower hillside portion (sub 61 to sub $90=$ sub-unities sequentially numbered, samples collected inside each sampling unit of PELD) indicate possible higher organic matter contents. According to Vieira et al., (1988), the redox environment, with poorly drained lowlands, generally present less stony and darker soils, due to organic matter content. Moreno and Schiavini (2001) also demonstrated that forest 
microenvironments subjected to soil flooding allow accumulation of organic matter and thus soil color tends to be darker.

With the increase of topographic position and declivity, sub-units of the middle hillside (sub 121 to sub 180) suffer great alterations in their edaphic characteristics and hydric availability (reduction of water content), and present a varied range of soil color conditions and stoniness (Figure 1). In these terms, their behavior brought changes in soil color from grayish in the lower hillside regions to reddish and dark red in the middle hillside. Hence, the great variation in stones and boulders quantity exposed to soil surface (stoniness), in middle hillside sampling sub-unities, is due to different declivities which define distinct movement intensities of stone blocks falling from the upper hillside.

In the ordination graphic, as can be seen, some sampling sub-units of the lower and middle hillside appear spatially close each other (Figure 1), which indicates environmental similarity of these two topographic positions.

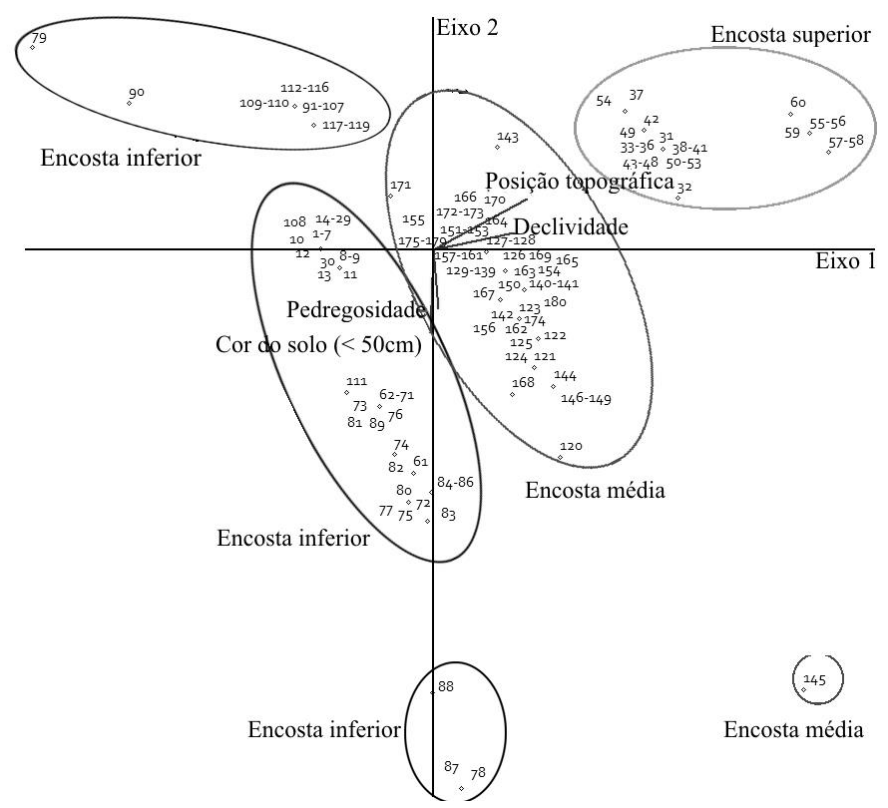

Figure 1. Ordination diagram of 180 sample sub-units (SSUs) in the two first axis of the canonical correspondence analysis model for three different topographical gradients of the Mixed Ombrophilous Forest hillside: 90 SUs in lower hillside, 60 SUs in middle hillside and 30 SUs in upper hillside.

Figura 1. Diagrama de ordenação das 180 subunidades amostrais (UAs) nos dois primeiros eixos do modelo de análise de correspondência canônica para três diferentes posições topográficas de uma encosta com Floresta Ombrófila Mista: 90 UAs na encosta inferior, 60 UAs na encosta média e 30 UAs na encosta superior.

The sampling sub-units of the upper hillside topographic position (sub 31 to sub 60) were distributed in the positive quadrant of the first ordination axis and were positively influenced by topographic position (0.835) and declivity (0.715), causing changes of soil color in the surface layer (0.771 ) and superficial stoniness (-0.552) (Table 2). This behavior was expected, because according to Streck et al. (2008); Santos et al. (2013), elevation of the topographic position is associated to environments with lower organic matter content and reddish tones, caused by presence of hematite.

The first CCA ordination axis revealed the greatest variability in the distribution of species along the topographic gradient (Figure 2). Seen in these terms, just nine forest species could be observed as having a preferential distribution to the environmental conditions of the upper hillside, same species that in other studies were cited as typical of well drained hillsides: Mollinedia elegans Tul. (CHAMI et al. 2011), Myrciaria delicatula (DC.) O. Berg, Podocarpus lambertii Klotzsch ex Endl., Ocotea pulchella (Nees) Mez (MARTINS-RAMOS et al., 2011), Ilex dumosa Reissek, Duranta vestita Cham., Rudgea 
parquioides, Siphoneugena reitzii D. Legrand, Lamanonia ternata Vell. (BRACK et al., 2006) and Zanthoxylum petiolare A. St.-Hil. \& Tul. (COWAN; SMITH, 1973). All these species also presented high individual density in the upper hillside position (Table 1).

In the lower hillside position, eleven forest species showed relationship with this topographic condition, and these too are registered in other studies as having the same environmental preferences associated to more humid sites: Stillingia oppositifolia (BACKES; NARDINO, 1998), Picramnia parvifolia Engl. (CARVALHO et al. 2009), Myrcia oligantha O. Berg (LÓPEZ et al. 2006), Myrceugenia myrcioides (Cambess.) O. Berg, Calyptranthes concinna, Campomanesia rhombea, Eugenia subterminalis DC., Eugenia uruguayensis Cambess. (LEGRAND; KLEIN, 1969, 1970, 1978), Myrceugenia cucullata, Myrciaria floribunda (West ex Willd.) O. Berg, Myrrhinium atropurpureum Schott (MARCHIORI; SOBRAL, 1997) and Lonchocarpus nitidus (Vogel) Benth (SILVA; TOZZI, 2012). This standard of ecological colonization adapted to humid environments is proved by the great density of individuals (Table 1).

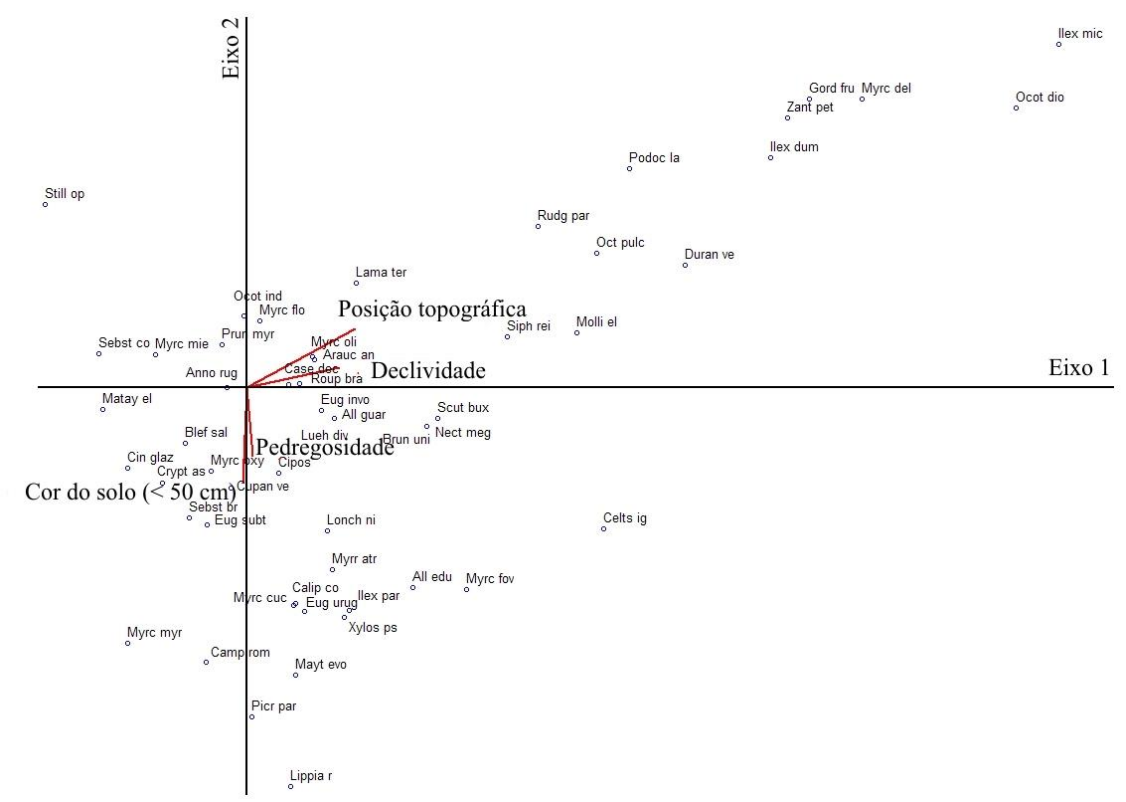

Figure 2. Ordination diagram of species in the first two axes held by the canonical correspondence analysis, based on density distribution of species under natural regeneration process in 180 sampling sub-units of the Mixed Ombrophilous Forest at São Francisco de Paula National Forest, RS, Brazil.

Figura 2. Diagrama de ordenação das espécies nos dois primeiros eixos produzidos pela análise de correspondência canônica, baseada na distribuição da densidade de espécies da regeneração natural em 180 subunidades amostrais da Floresta Ombrófila Mista na FLONA de São Francisco de Paula, RS, Brasil.

A great number of species did not show positive correlations with the edaphic characteristics demonstrated in stands/positions of the hillside (Figure 2). This lack of correlation may be partly explained by edaphic similarity registered between the lower and middle hillside sub-unities, demonstrated by their spatial proximity in the bi-dimensional ordination graphic (Figure 1). On the other hand, lack of correlation may indicate that forest species may present great establishment and growth adaptability to these edaphic variables, measured and selected in the model, thus not limiting their colonization only in the lower or middle hillside positions

Indication of the existence of three floristic groups in the same studied area (species typical of the lower, middle and upper hillside positions), demonstrated by Narvaes et al. (2008) by cluster analysis (Twinspan), revealed similar relationship to results of the Canonical Correspondence Analysis (Figure 1).

The preferential colonization standard of few species to an existent topographic position was mainly determined by declivity, which directly affected stoniness and soil color in the first layer. The 
same kind of colonization standards of species restricted to determined environmental conditions, depending on different topographic positions, using CCA in different native forest formations, were also proved by studies of Oliveira-Filho et al (1998); Pinder and Rosso (1998); Moreno and Schiavini (2001); Botrel et al. (2002); Cardoso and Schiavini (2002), Martins et al. (2003) and Scipioni et al. (2010).

Thus, the model proved to be efficient, since it clearly distinguished groups of sampling subunities typical of each topographic position, although did not reveal clear distribution standards for the majority of species along the altitude gradient. This condition reveals that the majority of species presented wide edaphic adaptation to different environments in terms of establishment and growth. Meanwhile, the model proved that there is a group of species with specific environmental adaptations (declivity, stoniness and soil color) to the lower and upper hillside positions.

\section{CONCLUSIONS}

Basing on results obtained it was concluded that:

- Sampling units of the forest inventory characterized the variations of the hillside topographic gradient. Darker and deeper soils (richer in organic matter) prevailed in the lower hillside portions when compared to upper/top hillside portions, which were thinner and with less organic matter content. Middle hillside portions presented intermediate environmental conditions, however, they showed more similarities with the lower hillside positions.

- Out of the 53 studied species, $22(41.5 \%)$ presented a distribution along the topographic gradient which was conditioned by declivity variations, stoniness and soil color $(50 \mathrm{~cm}$ depth). Species which presented greater correlations with the upper hillside conditions were: Mollinedia elegans, Myrciaria delicatula, Podocarpus lambertii, Ocotea pulchella, Ilex dumosa, Duranta vestita, Rudgea parquioides, Siphoneugena reitzii, Lamanonia ternata and Zanthoxylum petiolare. Species which presented greater correlations with the lower hillside conditions were: Stillingia oppositifolia, Picramnia parvifolia, Myrcia oligantha, Myrceugenia myrcioides, Calyptranthes concinna, Campomanesia rhombea, Eugenia subterminalis, Eugenia uruguayensis, Myrceugenia cucullata, Myrciaria floribunda, Myrrhinium atropurpureum and Lonchocarpus nitidus. All other considered species might be considered as widely adapted to the different hillside conditions.

- Preference of these species for determined soil condition in different hillside positions should be taken in consideration by the different recuperation/reforestation or silvicultural programs, when conducted in irregular relief areas of the Mixed Ombrophilous Forest in Rio Grande do Sul.

\section{REFERENCES}

ANGIOSPERM PHYLOGENY GROUP (APG III). An update of the Angiosperm Phylogeny Group classification for the orders and families of flowering plants: APG III. The Botanical Journal of the Linnean Society, London, v. 161, p. 105 - 121, 2009.

ÁVILA, A. L.; ARAUJO, M. M.; LONGHI, S. J.; GASPARIN, E. Agrupamentos florísticos na regeneração natural em remanescente de Floresta Ombrófila Mista, RS, Brasil. Scientia Forestalis, Piracicaba, v. 39, n. 91, p. 331 - 342, 2011.

BACKES, A.; NARDINO, M. Árvores, arbustos e algumas lianas nativas no Rio Grande do Sul. São Leopoldo: UNISINOS, 1998. 202 p.

BARIK, S. K.; TRIPATHI, R. S.; PANDEY, H. N.; RAO, P. Tree regeneration in a subtropical humid forest: effect of cultural disturbance on seed production, dispersal and germination. Journal of Applied Ecology, London, v. 33, p. 1551 - 1560, 1996.

BLANC, L.; MAURY-LECHON, G.; PASCAL, J. P. Structure, floristic composition and natural regeneration in the forests of Cat Tien National Park, Vietnam: an analysis of the successional trends. Journal of Biogeography, Oxford, v. 27, p. 141 - 157, 2000.

BOTREL, T. R.; OLIVEIRA-FILHO, A. T.; RODRIGUES, L. A.; CURI, N. Influência do solo e topografia sobre as variações da composição florística e estrutura da comunidade arbóreo-arbustiva de uma floresta estacional semidecidual em Ingaí, MG. Revista Brasileira de Botânica, São Paulo, v. 25, n. 
2, p. 195 - 213, 2002.

BRACK, P.; SINGER, R. F.; CASAGRANDE, A.; PEDROLLO, C. T.; MILANESI, L. S.; GRINGS, M.; PANIZZI, R.; TALBOT, V. Levantamento preliminar da flora e da vegetação do vale do rio Pelotas, no município de Bom Jesus, RS, e a importância de sua conservação. 2006. Disponível em: < http://www.inga.org.br/docs/levantamento_preliminar_vegetacao_paiquere.pdf >. Acesso em: 12/02/2013.

CARDOSO, E.; SCHIAVINI, I. Relação entre distribuição de espécies arbóreas e topografia em um gradiente florestal na Estação Ecológica do Panga (Uberlândia, MG). Revista Brasileira de Botânica, São Paulo, v. 25, n. 3, p. 277 - 289, 2002.

CARVALHO, J.; MARQUES, M. C. M.; RODERJAN, C. V.; BARDDAL, M.; SOUSA, S. G. A. Relações entre a distribuição das espécies de diferentes estratos e as características do solo de uma floresta aluvial no estado do Paraná, Brasil. Acta Botanica Brasilica, São Paulo, v. 23, n. 1, p. 1 - 9, 2009.

CATTANIO, J. H.; ANDERSON, A. B.; CARVALHO, M. S. Floristic composition and topographic variation in a tidal floodplain forest in the Amazon Estuary. Revista Brasileira de Botânica, São Paulo, v. 25, n. 4, p. 419 - 430, 2002.

CHAMI, L. B.; ARAUJO, M. M.; LONGHI, S. J.; KIELSE, P.; LUCIO, A. D. Mecanismos de regeneração natural em diferentes ambientes de remanescente de Floresta Ombrófila Mista, São Francisco de Paula, RS. Ciência Rural, Santa Maria, v. 41, n. 2, p. 251 - 259, 2011.

COWAN, R. S.; SMITH, L. B. Rutáceas. In: REITZ, P. R. (Ed.). Flora Ilustrada Catarinense. Itajaí: Herbário Barbosa Rodrigues, 1973. 89 p.

FAVERO, L. P.; BELFIORE, P.; SILVA, F. L.; CHAN, B. L. Análise de dados: modelagem multivariada para tomada de decisões. Rio de Janeiro: Elsevier, 2009. 646 p.

GOTELli, N. J.; ELLISON, A. M. Princípios de estatística em ecologia. Porto Alegre: Artmed, 2011. $528 \mathrm{p}$.

GRAF NETO, J. Crescimento, recrutamento e mortalidade no período de 2001 - 2010 de uma Floresta Ombrófila Mista Aluvial, município de Araucária, Paraná. 118 f. Dissertação (Mestrado em Ciências Florestais) - Universidade Federal do Paraná, Curitiba, 2011.

LADEIRA, H. P. Quatro Décadas de Engenharia Florestal no Brasil. Viçosa: Sociedade de Investigações Florestais, 2002. 207 p.

LEGRAND, C. D.; KLEIN, R. M. Mirtáceas: 2. Eugenia. In: REITZ, P. R. (ed.). Flora Ilustrada Catarinense. Itajaí: Herbário Barbosa Rodrigues, 1969. 63 p.

LEGRAND, C. D.; KLEIN, R. M. Mirtáceas: 4. Myrceugenia. In: REITZ, P. R. (ed.). Flora Ilustrada Catarinense. Itajaí: Herbário Barbosa Rodrigues, 1970. 123 p.

LEGRAND, C. D.; KLEIN, R. M. Mirtáceas: 17. Myrciaria. In: REITZ, P. R. (ed.). Flora Ilustrada Catarinense. Itajaí: Herbário Barbosa Rodrigues, 1978. 146 p.

LÓPEZ, A.; BICERRA, E.; DÍAZ, E. Perfil ecológico de cuatro rodales de camu camu árbol Myrciaria floribunda (H. West. ex Willd) O. Berg. en Ucayali. Ecologia Aplicada, Lima, v. 5, n. 1 - 2, p. 45 - 52, 2006.

MARCHIORI, J. N. C. Fitogeografia do Rio Grande do Sul: Enfoque Histórico e Sistemas de Classificação. Porto Alegre: Ed. EST, 2002. 118 p.

MARCHIORI, J. N. C.; SOBRAL, M. Dendrologia das angiospermas - Myrtales. Santa Maria: Editora UFSM, 1997. 304 p.

MARTINS, S. V.; SILVA, N. R. S.; SOUZA, A. L.; NETO, J. A. A. M. Distribuição de espécies arbóreas em um gradiente topográfico de Floresta Estacional Semidecidual em Viçosa, MG. Scientia Forestalis, Piracicaba, n. 64, p. 172 - 181, 2003. 
MARTINS-RAMOS, D.; CHAVES, C. L.; BORTOLUZZI, R. L.; MANTOVANI, A. Florística de Floresta Ombrófila Mista Altomontana e de Campos em Urupema, Santa Catarina, Brasil. Revista Brasileira de Biociências, Porto Alegre, v. 9, n. 2, p. 156 - 166, 2011.

Mc CUNE, B.; MEFFORD, M. J. PC-ORD. Multivariate Analysis of Ecological Data Version 2.0. Oregon, USA: $1995.126 \mathrm{p}$.

Mc CUNE, B.; MEFFORD, M. J. PC-ORD. Multivariate Analysis of Ecological Data Version 3.17. Oregon, USA, 1997. 40 p.

MORENO, J. A. Clima do Rio Grande do Sul. Porto Alegre: Secretaria da Agricultura, 1961. 42 p.

MORENO, M. C.; SCHIAVINI, I. Relação entre vegetação e solo em um gradiente florestal na Estação Ecológica do Panga, Uberlândia (MG). Revista Brasileira de Botânica, São Paulo, v. 24, n. 4, p. 537 544, 2001.

MUNSELL COLOR COMPANY. Munsell Soil Color Charts. Baltimore, Maryland: Ed. Kollmorgin Corporation, 1971. $18 \mathrm{p}$.

NARVAES, I. S. Classificação e caracterização da regeneração natural em Floresta Ombrófila Mista na Floresta Nacional de São Francisco de Paula, RS. 143 f. Dissertação (Mestrado em Engenharia Florestal) - Universidade Federal de Santa Maria, Santa Maria, 2004.

NARVAES, I. S.; LONGHI, S. J.; BRENA, D. A. Estrutura da regeneração natural em Floresta Ombrófila Mista na Floresta Nacional de São Francisco de Paula, RS. Ciência Florestal, Santa Maria, v. 15, n. 4, p. $331-342,2005$.

NARVAES, I. S.; LONGHI, S. J.; BRENA, D. A. Florística e classificação da regeneração natural em Floresta Ombrófila Mista na Floresta Nacional de São Francisco de Paula, RS. Ciência Florestal, Santa Maria, v. 18, n. 2, p. 233 - 245, 2008.

NIMER, E. Clima. In: INSTITUTO BRASILEIRO DE GEOGRAFIA E ESTATÍSTICA (IBGE). Geografia do Brasil: Região Sul. Rio de Janeiro: IBGE, 1990. p. 151 - 187.

OLIVEIRA-FILHO, A. T.; CURI, N.; VILELA, E. A.; CARVALHO, D. A. Effects of Canopy Gaps, Topography, and Soils on the Distribution of Woody Species in a Central Brazilian Deciduous Dry Forest. Biotropica, Zurich, v. 30, n. 3, p. 362 - 375, 1998.

PINDER, L.; ROSSO, S. Classification and ordination of plant formations in the Pantanal of Brazil. Plant Ecology, Amsterdam, v. 136, p. 151 - 165, 1998.

SANTOS, H. G. dos; JACOMINE, P. K. T.; ANJOS, L. H. C. dos; OLIVEIRA, V. A. de; LUMBRERAS, J. F.; COELHO, M. R.; ALMEIDA, J. A. de; CUNHA, T. J. F.; OLIVEIRA, J. B. de. Sistema brasileiro de classificação de solos. 3ed. Rev. Ampl. Brasília, DF. EMBRAPA, 2013. 353 p.

SCIPIONI, M. C.; LONGHI, S. J.; REINERT, D. J.; ARAÚJO, M. M.; PEDRON, F. A. Distribuição do compartimento arbóreo em gradiente de relevo e solos na encosta Meridional da Serra Geral, RS. Ciência Rural, Santa Maria, v. 40, p. 1295 - 1301, 2010.

SILVA, M. J.; TOZZI, A. M. G. A. Revisão taxonômica de Lonchocarpus s. str. (Leguminosae, Papilionoideae) do Brasil. Acta Botanica Brasilica, São Paulo, v. 26, n. 2, p. 357 - 377, 2012.

STRECK, E. V.; KAMPF, N.; DALMOLIN, R. S. D.; KLAMT, E.; NASCIMENTO, P. C.; SCHNEIDER, P.; GIASSON, E.; PINTO, L. F. S. Solos do Rio Grande do Sul. Porto Alegre: EMATER/RS - ASCAR; UFRGS, 2008. 222 p.

TER BRAAK, C. J. F. The analysis of vegetation-environment relationship by canonical correspondence analysis. Vegetatio, New York, v. 69, p. 69 - 77, 1987.

TER BRAAK, C. J. F. Ordination. In: JONGMAN, R. H. G., TER BRAAK, C. J. F.; VAN TONGEREN, O. F. R., eds. Data analysis in community and landscape ecology. Cambrigde: Cambrigde University Press, 1995. p. 91 - 173. 
VALERIANO, M. M.; ROSSETTI, D. F. Topodata: Brazilian full coverage refinement of SRTM data. Applied Geography (Sevenoaks), v. 32, p. 300 - 309, 2012.

VIEIRA, L. S.; DOS SANTOS, P. C. T. C.; VIEIRA, M. N. F. Solos: propriedade, classificação e manejo. Brasília: MEC/ABEAS, 1988, 154 p. 